\title{
Atypical chronic myeloid leukaemia: cytogenetic and molecular testing - a clincher to final diagnosis
}

\author{
Smeeta Gajendra, ${ }^{1}$ Anil Yadav, ${ }^{2}$ Manorama Bhargava ${ }^{2}$
}

'Laboratory Oncology, All India Institute of Medical Sciences, New Delhi, Delhi, India ${ }^{2}$ Department of Hematopathology, Medanta The Medicity Hospital, Gurgaon, Haryana, India

\section{Correspondence to} Dr Smeeta Gajendra; drsmeeta@gmail.com

Accepted 17 June 2021

\section{Check for updates}

(C) BMJ Publishing Group Limited 2021. No commercial re-use. See rights and permissions. Published by BMJ.

To cite: Gajendra S, Yadav A, Bhargava M. BMJ Case Rep 2021;14:e244378. doi:10.1136/bcr-2021244378

\section{DESCRIPTION}

A 66-year-old woman presented with melena for 5 months with an episode of haematemesis. Ultrasonography revealed hepatosplenomegaly. Her complete blood count showed anaemia (haemoglobin of $44 \mathrm{~g} / \mathrm{L}$ ), hyperleucocytosis (total leucocyte count $323.99 \times 10^{9} / \mathrm{L}$ ) and thrombocytopenia (platelets of $40 \times 10^{9} / \mathrm{L}$ ). Peripheral blood showed hyperleucocytosis with neutrophil and myelocyte bulge with complete differential count of neutrophils: $47.0 \%$, lymphocytes: $2.5 \%$, eosinophils: $1.5 \%$, monocytes: $1.5 \%$, basophils: $1.5 \%$, metamyelocytes: $4.5 \%$, myelocytes: $37.5 \%$; blasts: $4.0 \%$; and thrombocytopenia (figure 1A). Bone marrow aspirate (figure 1B) was hypercellular showing myeloid hyperplasia with 5\% blasts (myelogram: blasts: $5.0 \%$, myelocytes: $23.6 \%$, metamyelocytes: 4.4\%, neutrophils: $57.4 \%$, eosinophils and its precursors: $0.2 \%$, lymphocytes: $1.4 \%$, monocytes: $0.2 \%$, plasma cells: $0.2 \%$, erythroid precursors: 7.2\%, basophils: $0.4 \%$ ). Trilineage dysplasia was also noted. Bone marrow biopsy was hypercellular showing myeloid hyperplasia with small focal areas of increase reticulin fibrosis. Karyotype showed 47,XX, trisomy 8 (figure 1C). Fluorescence in situ hybridisation (FISH) was negative for $\mathrm{t}(9 ; 22) / B$ CR-ABL1 (figure 1D). Real-time PCR for p210, p230 and p190 BCR-ABL1 transcripts was also negative. Molecular studies for JAK2, CALR and $M P L$ were also found negative. A final diagnosis of atypical chronic myeloid leukaemia (aCML) was

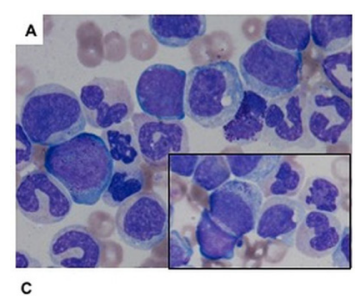

c

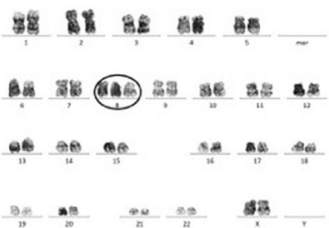

Figure 1 (A) Peripheral blood showed hyperleucocytosis with neutrophil and myelocyte bulge and dysgranulopoiesis. (B) Bone marrow aspirate hypercellular showing myeloid hyperplasia with trilineage dysplasia. (C) Karyotype showed 47,XX, trisomy 8. (D) Fluorescence in situ hybridisation showed negative for $\mathrm{t}(9 ; 22) / B C R-A B L 1$. made. Atypical CML belongs to the group of myelodysplastic/myeloproliferative neoplasms (MDS/ MPN). Although a definite cytogenetic or molecular signature is absent in aCML, most common karyotypic changes reported in aCML include trisomy 8 and del (20q). Abnormalities involving other chromosomes such as 12,13, 14, 17, 19 and 21 have also been described. ${ }^{1}$ Persistent leucocytosis without monocytosis with absence of Philadelphia $(\mathrm{Ph})$ chromosome and BCR/ABL fusion gene suggests a diagnosis of aCML. Evidence of marked multilineage dysplasia is an important morphological finding indicating aCML. Differential diagnosis of aCML is CML, myelofibrosis, chronic neutrophilic leukaemia (CNL) and chronic myelomonocytic leukaemia (CMML). ${ }^{2}{ }^{3} \mathrm{CML}$ is mostly characterised by hyperleucocytosis with prominence of myelocytes (usually $>20 \%$ ), basophilia, presence of $B C R-A B L 1$ without significant dyshaematopoiesis. In contrast to that, aCML does not show myelocyte prominence (myelocytes are usually $10 \%-20 \%$ ) with the presence of granulocytic dyspoiesis; and without basophilia and $B C R-A B L 1$ translocation. Myelofibrosis shows

\section{Patient's perspective}

Two months ago, I was suffered from melena, hematemesis and hepatosplenomegaly. I am feeling better now and we would like to thank technologists, consultants of diagnostic and clinical department for their excellent technical assistance. I am also indebted to the inpatient nursing teams and support staff for the excellent care they provided.

\section{Learning points}

- In the WHO 2016 classification, atypical chronic myeloid leukaemia (aCML) is defined as myelodysplastic/myeloproliferative neoplasms disease with an incidence approximately 100 times lower than the incidence of $B C R-A B L 1$ positive CML.

- No specific chromosomal abnormality is associated with aCML.

- Other myeloproliferative neoplasms pose diagnostic dilemma for aCML; however, the presence of a granulocytic proliferation associated with marked dysgranulopoiesis and the absence of $B C R-A B L 1$ translocation are the defining features of aCML. 
leucoerythroblastic anaemia with the presence of tear drop cells, increase marrow fibrosis and JAK2, CALR or MPL mutation. CMML is characterised by monocytosis $>1 \times 10^{3} / \mu \mathrm{L}$ and CNL is characterised by neutrophilia with immature granulocytes $<10 \%$ and no dyshaematopoiesis. In our case, due to the presence of marked hyperleucocytosis $(>3 \mathrm{lakh} / \mu \mathrm{L}$ ) with myelocyte bulge without monocytosis, the closest differential diagnosis was CML in chronic phase. However, presence of dyspoiesis on morphological evaluation with absence of $\mathrm{Ph}$ chromosome on karyotype and FISH, and BCR/ABL fusion gene on real-time PCR, clinches the diagnosis.

Contributors SG conceived and drafted the first manuscript. AY performed FISH and karyotyping. SG and MB diagnosed the case, worked on the acquisition of data, and its interpretation, and contributed to subsequent revisions of the manuscript. All authors have seen and agree with the final version.

Funding The authors have not declared a specific grant for this research from any funding agency in the public, commercial or not-for-profit sectors.

Competing interests None declared.

Patient consent for publication Obtained.

Provenance and peer review Not commissioned; externally peer reviewed.

\section{REFERENCES}

1 Tefferi A, Gilliland G. Classification of chronic myeloid disorders: from Dameshek towards a semi-molecular system. Best Pract Res Clin Haematol 2006:19:365-85.

2 Gao T, Yu C, Xia S, et al. A rare atypical chronic myeloid leukemia BCR-ABL1 negative with concomitant JAK2 V617F and SETBP1 mutations: a case report and literature review. Ther Adv Hematol 2020:11:2040620720927105.

3 Belkhair J, Raissi A, Elyahyaoui H, et al. Atypical chronic myeloid leukemia Bcr-Abl 1 negative: a case report and literature review. Leuk Res Rep 2019;12:100172.

Copyright 2021 BMJ Publishing Group. All rights reserved. For permission to reuse any of this content visit

https://www.bmj.com/company/products-services/rights-and-licensing/permissions/

BMJ Case Report Fellows may re-use this article for personal use and teaching without any further permission.

Become a Fellow of BMJ Case Reports today and you can:

- Submit as many cases as you like

- Enjoy fast sympathetic peer review and rapid publication of accepted articles

- Access all the published articles

Re-use any of the published material for personal use and teaching without further permission

Customer Service

If you have any further queries about your subscription, please contact our customer services team on +44 (0) 2071111105 or via email at support@bmj.com.

Visit casereports.bmj.com for more articles like this and to become a Fellow 